\title{
Cérebro e coração: de Pascal aos educadores
} Brain and heart: Pascal to educators

A gente ajeita o cabelo todos os dias; por que não o coração? Com esse provérbio chinês na cabeça, eu tinha que me lembrar de Pascal, o filósofo francês do século XVII que, na história da filosofia, foi quem soube explorar, com brilho, o papel existencial do coração humano.

Em sua obra mais conhecida, Pensamentos,${ }^{1}$ ele soube destacar incisivamente nossa porção emocional, imantada pelo coração, distinguindo-a da razão, nossa parte intelectual. Ele nos faz pensar no coração não como órgão muscular que recebe e bombeia sangue, no ritmo das sístoles e diástoles, mas como a sede das nossas sensações. Se a razão tem sua ordem, seus princípios e suas orientações, o coração segue outra linha, feita de impulsos e surpresas, ao calor das diferentes situações de cada dia.

Pascal foi matemático, físico e pesquisador e criou até uma calculadora mecânica, chamada depois de pascalina, o antepassado remoto do computador. Eu, no entanto, prefiro vê-lo como o filósofo que, de forma inapelável, declarou: "É loucura seguir só a razão" e deu a famosa justificativa: "O coração tem suas razões, que a razão não conhece", ou seja, há que se cultivar dois tipos de conhecimento: o discursivo e o intuitivo.

Sem dúvida, o diferencial humano está no pensar, no que o filósofo chama de espírito geométrico, mas o privilégio desse dom precisa passar pelo crivo da sensibilidade, o espírito de fineza, porque o homem "é um caniço que pensa, mas um caniço".

Deduzo dessas reflexões de Pascal que a vida deve ser levada com o equilíbrio entre cérebro e coração. Por outras palavras, para evitar o frio monopólio do raciocínio, valorize-se também o vigor dos sentimentos, das experiências sensoriais, do prazer estético, da espiritualidade, de tudo, enfim, que transcenda nossa crua animalidade. Do contrário, acabaremos classificados, em última instância, como um "bestarel", simples cruzamento de besta com bacharel, ou como um inexpressivo "intelijumento".

A visão racionalista da vida empobrece e desestimula as pessoas. Olhe-se, por exemplo, a educação nacional. Se todas as suas etapas, do ensino básico à faculdade, fossem marcadas por ideias claras e distintas, como propunha Descartes, mas também animadas por ideias emocionantes, como sugere Pascal, a sala de aula deixaria de ser espaço tão chato para os alunos e tão estressante para os professores.

Só se respiram bons ares em ambientes inspiradores, onde existe o gosto de aprender e o entusiasmo para ensinar, onde se sentem afeto e solidariedade, onde se tem contato com o novo e com o belo, com aquilo cuja percepção causa aprazer. E nunca foi tão necessário falar em beleza como neste tempo feio de muita barbárie e violência.

Penso, especialmente, na juventude. No mundo seco e desencantador que a cerca, anda muito difícil sentir a beleza da vida e apreciar a beleza na vida. Não que faltem estímulos. Abrem-se bons horizontes para quem sai atrás do diploma, do emprego, do sucesso pessoal, mas sem se fechar para o chamarisco transformador das artes, da ciência, da leitura, do companheirismo, do esporte, da fé e - por que não? - do engajamento político. Tudo isso é paixão. E vida sem paixão, só no caixão.

\section{REFERÊNCIA}

1. Pascal B. Pensamentos. $2^{\mathrm{a}}$ ed. São Paulo: Martins Fontes; 2005.

${ }^{1}$ Universidade de Sorocaba (UNISO) - Sorocaba (SP), Brasil.

Contato: aldo.vannucchi@uniso.br

Recebido em 21/01/2016. Aceito para publicação em 27/01/2016. 